\title{
Article \\ Preparation of Silicon Hydroxyapatite Nanopowders under Microwave-Assisted Hydrothermal Method
}

\author{
Zully Matamoros-Veloza ${ }^{1, *}$, Juan Carlos Rendon-Angeles ${ }^{2}{ }^{(\mathbb{D}}$, Kazumichi Yanagisawa $\left.{ }^{3}{ }^{(}\right)$, Tadaharu Ueda ${ }^{4,5}$, \\ Kongjun Zhu ${ }^{6}{ }^{\circledR}$ and Benjamin Moreno-Perez ${ }^{1}$ \\ 1 Graduate Division, Technological Institute of Saltillo, Tecnológico Nacional de México/(I.T. Saltillo), \\ Saltillo 25280, Mexico; bnmoreno24@gmail.com \\ 2 Centre for Research and Advanced Studies of the NPI, Cinvestav-Campus Saltillo, Saltillo 25900, Mexico; \\ jcarlos.rendon@cinvestav.edu.mx \\ 3 Research Laboratory of Hydrothermal Chemistry, Faculty of Science, Kochi University, Kochi 780-8520, Japan; \\ yanagi@kochi-u.ac.jp \\ 4 Department of Marine Resources Science, Faculty of Agricultural and Marine Science, Kochi University, \\ Nankoku 783-8502, Japan; chuji@kochi-u.ac.jp \\ 5 Center for Advanced Marine Core Research, Kochi University, Nankoku 783-8502, Japan \\ 6 State Key Laboratory of Mechanics and Control Mmechanics Structures, Nanjing University of Aeronautics \\ and Astronautics, Nanjing 210016, China; kjzhu@nuaa.edu.cn \\ * Correspondence: zully.mv@saltillo.tecnm.mx
}

check for

updates

Citation: Matamoros-Veloza, Z.; Rendon-Angeles, J.C.; Yanagisawa, K.; Ueda, T.; Zhu, K.; Moreno-Perez, B.

Preparation of Silicon Hydroxyapatite Nanopowders under MicrowaveAssisted Hydrothermal Method. Nanomaterials 2021, 11, 1548. https:// doi.org/10.3390/nano11061548

Academic Editors: Edward H. Lester, Elena Aznar and Frederik Tielens

Received: 18 March 2021

Accepted: 8 June 2021

Published: 11 June 2021

Publisher's Note: MDPI stays neutral with regard to jurisdictional claims in published maps and institutional affiliations.

\section{Copyright: (c) 2021 by the authors.} Licensee MDPI, Basel, Switzerland. This article is an open access article distributed under the terms and conditions of the Creative Commons Attribution (CC BY) license (https:/ / creativecommons.org/licenses/by/ $4.0 /)$.

\begin{abstract}
The synthesis of partially substituted silicon hydroxyapatite (Si-HAp) nanopowders was systematically investigated via the microwave-assisted hydrothermal process. The experiments were conducted at $150{ }^{\circ} \mathrm{C}$ for $1 \mathrm{~h}$ using TMAS $\left(\mathrm{C}_{4} \mathrm{H}_{13} \mathrm{NO}_{5} \mathrm{Si}_{2}\right)$ as a $\mathrm{Si}^{4+}$ precursor. To improve the $\mathrm{Si}^{4+}$ uptake in the hexagonal structure, the $\mathrm{Si}$ precursor was supplied above the stoichiometric molar ratio $(0.2 \mathrm{M})$. The concentration of the TMAS aqueous solutions used varied between 0.3 and $1.8 \mathrm{M}$, corresponding to saturation levels of 1.5-9.0-fold. Rietveld refinement analyses indicated that $\mathrm{Si}$ incorporation occurred in the HAp lattice by replacing phosphate groups $\left(\mathrm{PO}_{4}{ }^{3-}\right)$ with the silicate $\left(\mathrm{SiO}_{4}{ }^{-}\right)$group. FT-IR and XPS analyses also confirmed the gradual uptake of $\mathrm{SiO}_{4}{ }^{-}$units in the $\mathrm{HAp}$, as the saturation of $\mathrm{Si}^{4+}$ reached $1.8 \mathrm{M}$. TEM observations confirmed that Si-HAp agglomerates had a high crystallinity and are constituted by tiny rod-shaped particles with single-crystal habit. Furthermore, a reduction in the particle growth process took place by increasing the $\mathrm{Si}^{4+}$ excess content up to $1.8 \mathrm{M}$, and the excess of $\mathrm{Si}^{4+}$ triggered the fine rod-shaped particles self-assembly to form agglomerates. The agglomerate size that occurred with intermediate $(0.99 \mathrm{~mol} \%)$ and large (12.16 $\mathrm{mol} \%$ ) Si contents varied between 233.1 and $315.1 \mathrm{~nm}$, respectively. The excess of Si in the hydrothermal medium might trigger the formation of the Si-HAp agglomerates prepared under fast kinetic reaction conditions assisted by the microwave heating. Consequently, the use of microwave heating-assisted hydrothermal conditions has delivered high processing efficiency to crystallize Si-HAp with a broad content of $\mathrm{Si}^{4+}$.
\end{abstract}

Keywords: hydrothermal microwave assisted synthesis; silicon-hydroxyapatite; nano powders

\section{Introduction}

The preparation of biomaterials with similar chemical and physical properties to biological hydroxyapatite (HAp), in terms of their chemical and physical properties, involves the uptake of cations and anions in the hexagonal HAp structure. The incorporation of $\mathrm{Si}^{4+}$ ions into the $\mathrm{PO}_{4}{ }^{3-}$ unit network of the HAp stimulates both bone formation and resorption processes, which are relevant to both tissue restauration and bone growth [1]. Furthermore, the incorporation of $\mathrm{Si}^{4+}$ has been incorporated simultaneously with calcium during the early stage of calcination [2]. Additionally, silicon is also essential for other biological soft tissue functionality, such as cartilage growth, and synthetic calcium-phosphate bioceramics containing low $\mathrm{Si}^{4+}$ contents in their structures, which had marked biological 
properties for bone restauration [3,4]. Hitherto, Si-HAp bioceramics were prepared with a conventional solid-state reaction at $1000^{\circ} \mathrm{C}$ for $6 \mathrm{~h}$, employing $\beta$-tricalcium phosphate $\left(\beta-\mathrm{Ca}_{3}\left(\mathrm{PO}_{4}\right)_{2}\right)$, silicon dioxide $\left(\mathrm{SiO}_{2}\right)$, and calcium carbonate $\left(\mathrm{CaCO}_{3}\right)$. These partially silicon-substituted powders exhibit a good biological dissolution capability in comparison with pure HAp [5].

Moreover, chemical solution methods, such as coprecipitation, neutralization, and solgel, are alternative synthetic procedures for producing both HAp and Si-HAp nanoparticles. The increase of silicon incorporation in the HAp structure provokes a marked decrease in the crystallite size [6-11]. Likewise, silicon affects the particle morphology during the embryo precipitation and particle growth processes. Recently, extensive attention has been paid to the appropriated process with a $\mathrm{Si}^{4+}$ precursor reagent to overcome the difficulties in handling associated with its reactivity under wet chemical processing [4-15].

Hitherto, tetraethyl orthosilicate $\left(\mathrm{Si}\left(\mathrm{OCH}_{2} \mathrm{CH}_{3}\right)_{4}, \mathrm{TEOS}\right)$ in polyethylene glycol/water and silicon tetra-acetate in water $\left(\mathrm{Si}\left(\mathrm{CH}_{3} \mathrm{CO}_{2}\right)_{4}\right)$ have been better reagents for incorporating $\mathrm{Si}^{4+}$ in the hexagonal structure [13]. The maximum efficiency of the $\mathrm{Si}^{4+}$ incorporation in the apatite structure was $90 \%$ according to the nominal stoichiometric content of $8.0 \mathrm{~mol} \%$. Wet chemical quantitative analyses revealed the presence of silicon ions hydrolyzed in the remaining mother liquor after precipitation of SiHAp. In contrast, the challenge of producing synthetic Si-HAp has been carried out by various methods, including soft chemistry processes [5-13].

The slow reaction kinetic of the ions species to produce pure HAP and other solid solutions required prolonged processing time in specific systems [14-18].

The hydrothermal process has brought further advantages in terms of chemical reactivity: Higher yield for crystalline products with nanometric size and reaction kinetics enhancement even at relatively low temperatures $\left(100-250^{\circ} \mathrm{C}\right)[18,19]$.

Likewise, a few pioneering research works have reported the synthesis of partially substituted Si-HAp under hydrothermal conditions [12,14]. The synthesis was conducted by two pathways. The first experiments were conducted using the chemical reagents $\left(\mathrm{NH}_{4}\right)_{3} \mathrm{PO}_{4}$ and TEOS as precursor of $\mathrm{PO}_{4}{ }^{3-}$ and $\mathrm{SiO}_{4}{ }^{4-}$ ions. However, the synthesis conducted at $200{ }^{\circ} \mathrm{C}$ for $8 \mathrm{~h}$ limited the incorporation to only $8.0 \mathrm{~mol} \% \mathrm{Si}^{4+}$, regardless of the nominal stochiometric amount intended $(9.0 \mathrm{~mol} \%)[13,14]$. In other experiments, the uptake of $\mathrm{Si}^{4+}$ was further limited by using $\left(\mathrm{NH}_{4}\right)_{2} \mathrm{HPO}_{4}$ to $7.65 \mathrm{~mol} \%$. The partially substituted Si-HAp particles also incorporate $\mathrm{CO}_{3}{ }^{2-}$ ions, and the presence of these ions is reported to hinder the incorporation of $\mathrm{SiO}_{4}{ }^{4-}$ during the crystallization and particle coarsening steps $[13,20,21]$.

Similar experiments were recently conducted to attempted the synthesis of Si-HAp under hydrothermal conditions at $150^{\circ} \mathrm{C}$ for $10 \mathrm{~h}$ by employing tetramethyl ammonium silicate $\left(\left(\mathrm{C}_{4} \mathrm{H}_{13} \mathrm{NO}_{5} \mathrm{Si}_{2}\right)\right.$, TMAS) [1-3,13-16,18-20]. The low silicon reactivity in the hydrothermal alkaline medium at a $\mathrm{pH}$ of 10 caused a limited $\mathrm{Si}^{4+}$ content in the HAp structure of $30 \mathrm{~mol} \%$ regarding the stoichiometric amount selected $(1-20 \mathrm{~mol} \% \mathrm{Si})$. In this case, the incorporation of $\mathrm{CO}_{3}{ }^{2-}$ ions was not the cause of the significant $\mathrm{Si}$ uptake. The high solubility of the TMAS in the alkaline solution is likely to produce Si complex ions that are highly stable in the hydrothermal medium, giving rise to the decrease in the $\mathrm{Si}$ concentration in the embryo and growth steps [22,23].

A similar trend was found in the preparation of Zn-substituted HAp, where the isomorphous incorporation of $\mathrm{Zn}$ at the Ca site in the HAp structure was affected by the formation of $\mathrm{Zn}(\mathrm{OH})_{\mathrm{x}}{ }^{\mathrm{n}+}$ species, which were also stable in alkaline hydrothermal fluids at the standard $\mathrm{pH}$ conditions required to crystallize the HAp [20].

Although the detailed effect of the complex ion formation associated with the dopant ions in HAp has not been evaluated yet, it is important from the chemical processing point of view to enhance the control of the stoichiometry of $\mathrm{Ca}_{10}\left(\mathrm{PO}_{4}\right)_{6-x}\left(\mathrm{SiO}_{4}\right)_{x}(\mathrm{OH})_{2-\mathrm{x}}$ solid solutions and the particle growth at nanometer order [21,22]. In the present research work, different approaches for the synthesis of the $\mathrm{Ca}_{10}\left(\mathrm{PO}_{4}\right)_{6-x}\left(\mathrm{SiO}_{4}\right)_{x}(\mathrm{OH})_{2-x}$ particle were 
investigated, devoted to investigating the chemical reaction pathway in $\mathrm{Si}^{4+}$-saturated solutions under hydrothermal conditions assisted by microwave heating.

The fast reaction kinetics triggered by the microwave heating in conjunction with the saturation level of $\mathrm{Si}^{4+}$ would achieve a broad compositional control to produce $\mathrm{Ca}_{10}\left(\mathrm{PO}_{4}\right)_{6-x}\left(\mathrm{SiO}_{4}\right)_{x}(\mathrm{OH})_{2-x}$ compounds. The feasibility of controlling the particle size at nanometric order is likely to proceed due to Si complex ions in the hydrothermal medium, which would operate as templates in the particle crystallization process.

\section{Materials and Methods}

\subsection{Materials}

Preparation of the reagents for the synthesis of the stoichiometric pure hydroxyapatite (HAp) and silicon-substituted hydroxyapatite (Si-HAp) powders was carried out as follows; all the chemicals of reagent grade (Sigma Aldrich, St. Louis, MO, USA, 99.99\% purity) were used without further purification. The $1 \mathrm{M} \mathrm{Ca}^{2+}$ and $0.2 \mathrm{M} \mathrm{P}^{5+}$ stock solutions were prepared by dissolving calcium nitrate tetrahydrate $\left(\mathrm{Ca}\left(\mathrm{NO}_{3}\right)_{2} 4 \mathrm{H}_{2} \mathrm{O}\right)$ and sodium tripolyphosphate $\left(\mathrm{Na}_{5} \mathrm{P}_{3} \mathrm{O}_{10}\right)$ in distilled water, respectively. The $\mathrm{Si}^{4+}$ stock solutions of three different concentrations of $0.3,0.9$, and $1.8 \mathrm{M}$ were prepared by dissolving was tetramethylammonium silicate solution $\left[\left(\mathrm{C}_{4} \mathrm{H}_{13} \mathrm{NO}_{5} \mathrm{Si}_{2}\right)\right.$ (TMAS)]. Furthermore, all aqueous TMAS solutions were adjusted to $\mathrm{pH}=10$ with $7 \mathrm{M} \mathrm{NH}_{3}$ solution before making up the final volume of the TMAS stocks. The $7 \mathrm{M}$ of $\mathrm{NH}_{3}$ stock solution was prepared by mixing $82.6 \mathrm{~mL}$ of conc. $\mathrm{NH}_{3}$ solution with $17.35 \mathrm{~mL}$ of water. 2-Propanol was added as a buffer to prevent the formation of another phosphorous species during the reaction [23-25].

\subsection{Microwave-Assisted Hydrothermal Synthesis}

A mother solution constituted by $17.5 \mathrm{~mL}$ of the $1 \mathrm{M} \mathrm{Ca}^{2+}$ solution and $15 \mathrm{~mL}$ of 2-propanol was magnetically stirred for $5 \mathrm{~min}$. The added 2-propanol is used as a $\mathrm{pH}$ buffer to prevent the hydrolysis of calcium tripolyphosphate gel to orthophosphate ions. In parallel, a solution mixture $(17.5 \mathrm{~mL})$ containing $\mathrm{P}^{5+}$ and $\mathrm{Si}^{4+}$ ions was prepared according to the molar mixing $\mathrm{Ca} /(\mathrm{P}+\mathrm{Si})$ ratio of 1.67. Therefore, the mixture volumes calculated by the molar ratio Ca:P:Si were 17.5:0, 16.45:1.05, 15.75:1.75, and 14.0:3.5, where the molar volumes correspond to the pure HAp and the selected silicon compositions of 6,10 , and $20 \mathrm{~mol} \%$, respectively. To investigate the effect of the Si saturation in the mother liquor, the molar volumes calculated were provided with the silicon solutions of $0.3,0.9$, and $1.8 \mathrm{M}$ to investigate the effect of the Si saturation in the mother liquor, respectively. On mixing both solutions instantaneously, a white milky colloid formed, and the colloidal suspension was stirred constantly for $15 \mathrm{~min}$. Them, $\mathrm{pH}$ of the colloidal suspension was adjusted to a value of $10.00 \pm 0.1$ by adding a $7.0 \mathrm{M} \mathrm{NH}_{3}$ aqueous solution dropwisely $[1,14,20]$. The suspension $(50 \mathrm{~mL})$ was then transferred to a double-walled, Teflon, high-pressure vessel, hermetically closed, and placed in the rotatory device of the microwave oven (MARS-5X, CEM Corp., Manasquan, NJ, USA), and was heated at $150{ }^{\circ} \mathrm{C}$ for $1 \mathrm{~h}$. After the reaction, the powders were washed several times with deionized water until a neutral $\mathrm{pH}$ was achieved. The powder was dried using a freeze-drier $\left(-47^{\circ} \mathrm{C}, 3 \mathrm{MPa}\right)$ to avoid aggregation of the particles. The chemical reaction occurs as Equation (1) to crystallize $\mathrm{Ca}_{10}\left(\mathrm{PO}_{4}{ }^{3-}\right)_{6-x}\left(\mathrm{SiO}_{4}{ }^{4-}\right)_{\mathrm{x}}(\mathrm{OH})_{2-\mathrm{x}}$ nanoparticle crystallization under the proposed hydrothermal reaction assisted by microwave heating. In Equation (1), the ultimate content of $(\mathrm{Si}-\mathrm{O}-\mathrm{Si})_{3} \mathrm{O}^{-}$in the reaction products is equivalent to the subtraction of the $\mathrm{Si}^{4+}$ incorporated in the HAp and the nominal content supplied. Furthermore, $\mathrm{OH}^{-}$ deficiency in $\mathrm{Ca}_{10}\left(\mathrm{PO}_{4}{ }^{3-}\right)_{6-\mathrm{x}}\left(\mathrm{SiO}_{4}{ }^{4-}\right)_{\mathrm{x}}(\mathrm{OH})_{2-\mathrm{x}}$ results from the charge balance required to compensate the total negative valence of $\mathrm{SiO}_{4}{ }^{4-}$ groups incorporated in the HAp structure.

$$
\begin{gathered}
10 \mathrm{Ca}\left(\mathrm{NO}_{3}\right)_{2(\mathrm{aq})}+2\left(\mathrm{Na}_{5} \mathrm{P}_{3} \mathrm{O}_{10}\right)_{(\mathrm{aq})}+\mathrm{y}\left(\mathrm{C}_{4} \mathrm{H}_{13} \mathrm{NO}_{5} \mathrm{Si}_{2}\right)_{(\mathrm{aq})}+\mathrm{xNH}_{4} \mathrm{OH}_{(\mathrm{aq})}+\mathrm{x}\left(\mathrm{CH}_{3}\right)_{2} \mathrm{CHOH} \rightarrow \\
\left.\mathrm{Ca}_{10}\left(\mathrm{PO}_{4}{ }^{3-}\right)_{6-\mathrm{x}}\left(\mathrm{SiO}_{4}{ }^{4-}\right)_{\mathrm{y}}(\mathrm{OH})_{2-\mathrm{x}(\mathrm{s})}+10 \mathrm{Na}^{+}+\mathrm{xOH}^{-}{ }_{(\mathrm{aq})}+\mathrm{xNH}_{4}{ }^{\delta+} \mathrm{NO}_{3}{ }^{\delta-}{ }_{(\mathrm{aq})}+\mathrm{xH}_{2} \mathrm{O}+\mathrm{yCH} \mathrm{CH}_{4}{ }^{\delta+}+(\mathrm{y}-\mathrm{x})\left[(\mathrm{Si}-\mathrm{O}-\mathrm{Si})_{3} \mathrm{O}^{-}\right)\right]_{(\mathrm{aq})}
\end{gathered}
$$




\subsection{Characterization}

The crystalline phases of the obtained powders were determined by X-ray powder diffraction (XRD) analyses. Diffraction patterns were collected in a range $2 \theta$ from 10 to $80^{\circ}$ at a scanning speed of $4^{\circ} / \mathrm{min}$ and a step size of $0.02^{\circ}$ in a $2 \theta / \theta$ scanning mode using an X-ray diffractometer Rigaku Ultima IV equipped with $\mathrm{Cu} \mathrm{K} \alpha$ radiation $(\alpha=1.54056 \AA)$ operated at $40 \mathrm{kV}$ and $20 \mathrm{~mA}$. Furthermore, Rietveld refinement analyses of selected samples were carried out to determine the crystallite size and lattice parameters using the TOPAS 4.2 (Bruker AXS: Karlsruhe, Germany) software [19-21].

Fourier transform infrared (FT-IR) spectra were obtained at a wavelength range or $400-4000 \mathrm{~cm}^{-1}$ in the transmittance mode by FT-IR JASCO 4000 Hachioji (Tokyo, Japan) spectrometer, using palletized samples prepared with $5 \mathrm{mg}$ of powder sample and $200 \mathrm{mg}$ of $\mathrm{KBr}$. In addition, Raman spectra analyses were observed in the range $200-4000 \mathrm{~cm}^{-1}$ by laze excitation at $514 \mathrm{~nm}$ using a Jobin Yvon Labram HR800 Raman Spectrometer (Horiba, Japan).

The content of $\mathrm{Ca}, \mathrm{Si}$, and $\mathrm{P}$ in the residual powders was quantitatively calculated from the inductively coupled spectrometry analyses data (ICP, ICPE-9000; Shimadzu Co., Kyoto, Japan). XPS spectra were recorded on a Kratos spectrometer (Manchester, UK) operated using an $\mathrm{Al} \mathrm{Ka}(1486.6 \mathrm{eV})$ monochromatic X-ray source. The XPS analysis was carried out in ESCA Lab 220i-XL equipment (Shimadzu, Kyoto, Japan), at a vacuum of $2 \times 10^{-8}$ mTorr, and a monochromatic X-ray source with aluminum anode operated at $1486.6 \mathrm{eV}$ was used. The general spectra (survey) were obtained with a step energy of $117.4 \mathrm{eV}$, and the analysis region was $0-1400(\mathrm{eV})$ in link energy. Subsequently, highresolution spectra of the $\mathrm{C} 1 \mathrm{~s}, \mathrm{Ca} 2 \mathrm{p}, \mathrm{P} 2 \mathrm{p}$, and $\mathrm{O} 1 \mathrm{~s}$ signals were obtained for each sample. The high-resolution spectra were acquired with a step energy of $11.75 \mathrm{eV}$. Deconvolution of these spectra was performed by adjusting Gaussian curves, leaving their position and area without restriction. The FWHM value, however, remained fixed in each curve adjusted.

Morphology and particle size distribution were analyzed from the micrographs obtained by field emission scanning electron microscopy (FE-SEM JEOL 6500F JSM-7100F, Akishima, Tokyo, Japan) at $15 \mathrm{kV}$ and $69 \mu \mathrm{A}$ filament operating conditions. The image analysis was carried out using an Image-Pro ${ }^{\circledR}$ Plus software (Rockville, MD, USA). In addition, crystalline features were investigated by using the high-resolution observations conducted in the transmission electron microscopy (HR-TEM, FEI-TITAN 300, Phillips, Eugene, OR, USA) operated at $300 \mathrm{kV}$.

\section{Results and Discussion}

\subsection{Effect of $\mathrm{Si}^{4+}$ Saturation on the Hydrothermal Synthesis of Si-HAp}

Typical XRD patterns of the residual products prepared under microwave-assisted hydrothermal conditions at $150{ }^{\circ} \mathrm{C}$ for $1 \mathrm{~h}$ are shown in Figure 1. This experimental set was aimed to prepare $\mathrm{Ca}_{10}\left(\mathrm{PO}_{4}\right)_{6-x}\left(\mathrm{SiO}_{4}\right)_{x}(\mathrm{OH})_{2-x}$ solid solutions with nominal $\mathrm{Si}^{4+}$ content above the stoichiometric concentration of $0.2 \mathrm{M}$. Three levels of $\mathrm{Si}^{4+}$ saturation of 1.5, 4.5, and 9-fold were added to the hydrothermal medium employing the TMAS solutions of $0.3,0.9$, and $1.8 \mathrm{M}$, respectively. The $\mathrm{Si}^{4+}$ excess aimed to improve the efficiency in the incorporation of $\mathrm{Si}^{4+}$ ions substituting $\mathrm{P}^{5+}$ in the apatite hexagonal structure. In general, the diffraction patterns of the HAp and Si-HAp powders were indexed with that of the hexagonal apatite structure with space group $\mathrm{P}_{3} / \mathrm{m}$ (176) (card JCPD 09-0432). The crystallization of the HAp and Si-HAp proceeded via a single-step reaction; this assumption is inferred due to the formation of secondary phases of calcium phosphate or calcium silicate; it did not take place during the hydrothermal treatment. Generally, when the lowest saturation level of $\mathrm{Si}^{4+}$ (1.5) was used, the Si-HAp samples intended to incorporate 6 and $10 \mathrm{~mol} \%$ of Si did not have marked differences of peak intensity and sharpness from those of the pure HAp powders. The sample prepared with the 0.3 M TMAS solution with the volume to supply $0.33 \mathrm{~mol} \% \mathrm{Si}$ exhibited a slight shifting of the peak to a lower diffraction angle (Figure 1a). In contrast, at 4.5 and 9-fold saturation levels, a progressive displacement of the XRD pattern proceeded at small $2 \theta$ angles, and also a remarkable 
peak broadening occurred on the diffraction patterns, as shown in Figure 1b,c. This behavior was markedly evident in the Si-HAp samples prepared with amounts of 5.0 and $12.16 \mathrm{~mol} \% \mathrm{Si}$ with TMAS solutions of 0.9 and $1.8 \mathrm{M}$. Hence, the $\mathrm{Si}^{4+}$ excess in the aqueous phase plays an important role in promoting the uptake of $\mathrm{Si}$ during the crystallization of the single-phase Si-HAp powders. These crystalline aspects were not clearly analyzed for the Si-HAp prepared even in hydrothermal conditions elsewhere $[14,22,26]$, which do not bear crystalline structural evidence, indicating that the Si content reported is bulkily incorporated inside the particle rather than near the particle surface.
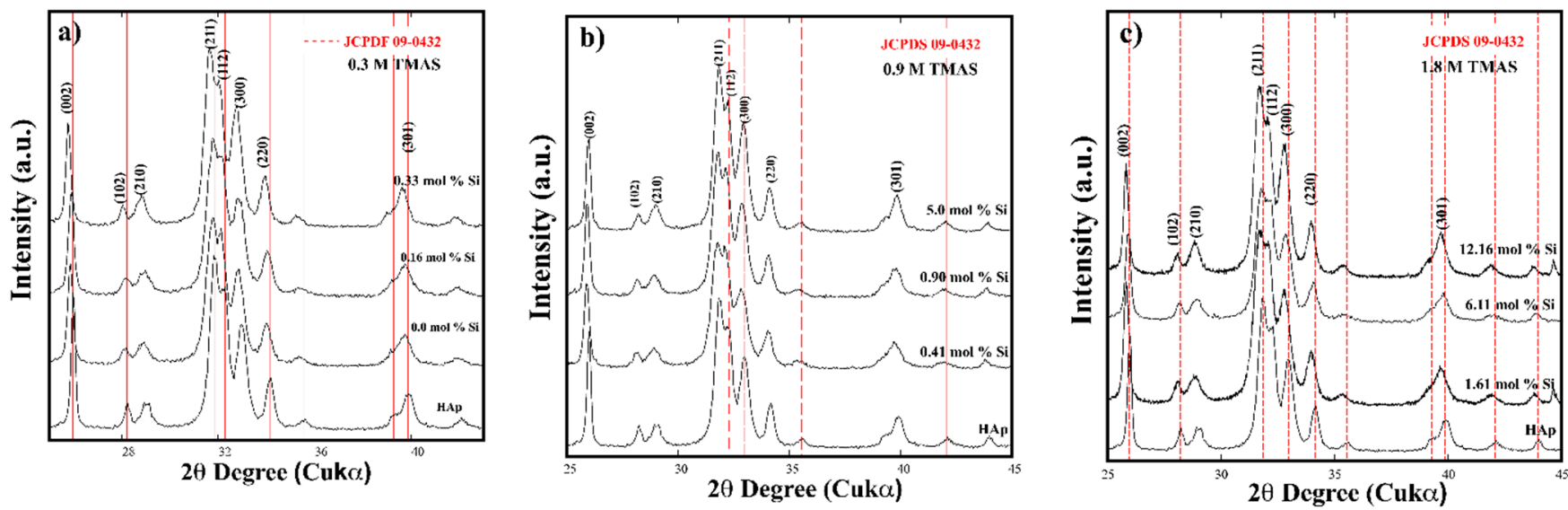

Figure 1. Si-HAp XRD patterns of samples synthesized under microwave-assisted hydrothermal conditions at $150{ }^{\circ} \mathrm{C}$ for $1 \mathrm{~h}, \mathrm{pH}=10$, using $0.2 \mathrm{M} \mathrm{Na}_{5} \mathrm{P}_{3} \mathrm{O}_{10}$ with different $\mathrm{Si}^{4+}$ mol\% using (TMAS), which was mixed with a molar excess of (a) $1.5(0.3 \mathrm{M})$, (b) $4.5(0.9 \mathrm{M})$, and (c) 9 (1.8 M) folds, above the stoichiometric concentration of $0.2 \mathrm{M}$ as shown.

\subsection{Crystalline Structural and Chemical Compositional Analyses of Si-HAp Powders}

The Rietveld refinement of Si-HA powders conducted with the refinement algorithm includes the $\mathrm{Si}^{4+}$ and $\mathrm{P}^{5+}$ molar contents determined by wet chemical analyses (Table 1 , ICP results), together with the atom occupation, as suggested elsewhere (Figure 2) $[1,2,5,8]$. Various crystalline structural features were included as the refinement parameters, such as background, lattice parameters, scale factor, profile half width, crystallite size, local strain, thermal isotropic vectors, and spatial coordinates. The parameters selected provided high accuracy for calculating the structural features of the Si-HAp powders. The Rietveld refinement approach provided the lowest values of the goodness-of-fit factor $\left(\mathrm{GOF} / \chi^{2}\right)$, averaging $1.23 \pm 0.6$, and low $R_{\mathrm{wp}} 7.32 \pm 1.0$ values were obtained (Table 1 ), which confirm the fine structure of all Si-HAp with excellent accuracy. The calculated diffraction profiles are in good agreement with the experimental ones due to the small residual difference between the observed and calculated patterns depicted by the residual straight line, and the vertical lines correspond to the calculated Bragg peaks positions (Figure 2) [8]. The calculated lattice parameters for pure HAp and Si-HAp are given in Table 1. Both the $a_{\mathrm{o}}$ and $c_{\mathrm{o}}$ axes increase slightly with the $\mathrm{Si}^{4+}$ incorporation into the pure HAp powders; whilst the length of both the $a_{\mathrm{o}}$ axis ( 9.4450 to $9.4365 \AA$ ) and the $c_{\mathrm{o}}$ axis (6.8882 to $6.8824 \AA$ ) decreased as the $\mathrm{Si}^{4+}$ incorporation ratio increased in Si-HAp powders, leading to the decrease in cell volume, specially shown in the Si-HAp powders prepared at a high $\mathrm{Si}^{4+}$ saturation level. It should be mentioned that in the case of Si-HAp powders at the maximum $\mathrm{Si}^{4+}$ incorporation of $12.16 \mathrm{~mol} \%$, the least " $a_{0}$ " and " $c_{0}$ " lattice parameters were obtained in comparison with those powders containing below $10 \mathrm{~mol} \%$ Si contents. These were caused by proportional release of $\mathrm{OH}^{-}$ions, which compensate the negative charges provided by $\mathrm{SiO}_{4}{ }^{4-}$ ions substituting $\mathrm{PO}_{4}{ }^{3-}$ in tetrahedral positions, located parallel to the $c$-axis along the tunnels located at the HAp structure honeycomb edges. This phenomenon provokes a bulk shrinkage of the hexagonal unit cell volume $\left(530.75 \AA^{3}\right)$ in the HAp structure, which would support the inference that $\mathrm{Si}$ is bulkily incorporated in the Si-HAp during 
the crystallization process, achieved by fast reaction kinetics triggered by the microwave heating under hydrothermal conditions. The maximum content of $\mathrm{Si}^{4+}(12.16 \mathrm{~mol} \%)$ incorporated in HAp in the current experiment is above that reached under conventional hydrothermal [22] and coprecipitation [4] conditions.

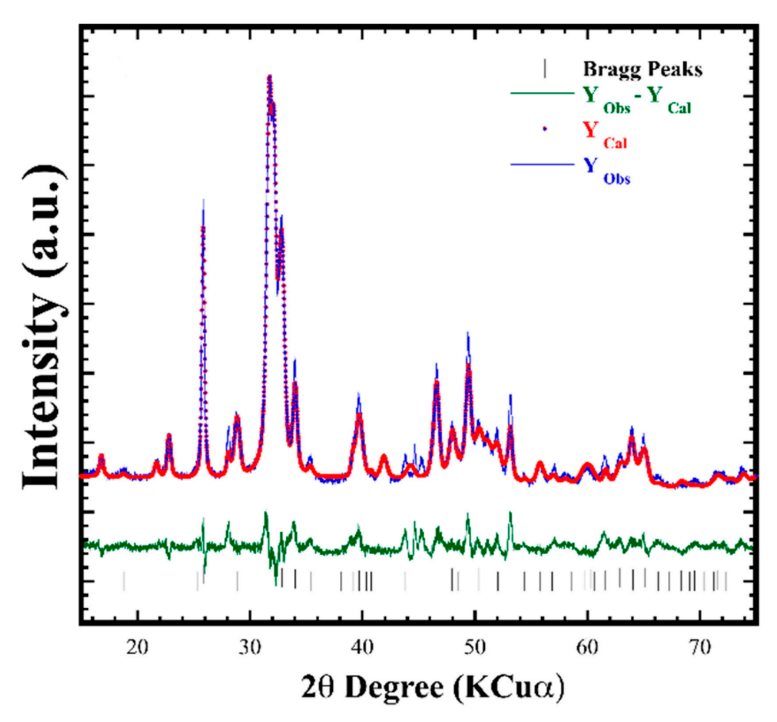

(a)

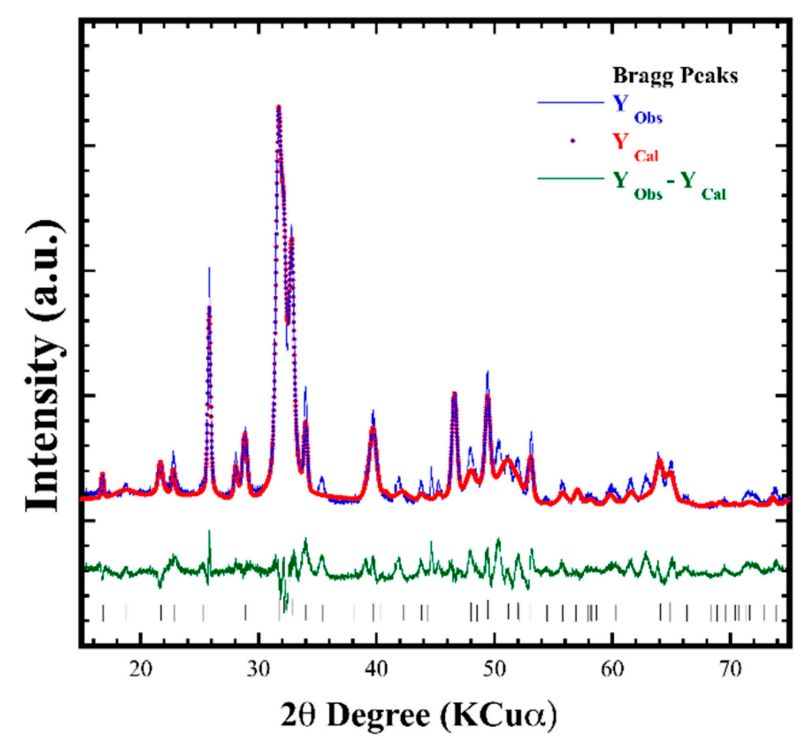

(b)

Figure 2. Rietveld refinement plot of Si-HAp powders prepared with different content of $\mathrm{Si}^{4+}$ : (a) $6 \mathrm{~mol} \%$ and (b) $20 \mathrm{~mol} \%$ using (TMAS) $\left[(\mathrm{CH} 3)_{4} \mathrm{~N}(\mathrm{OH}) .2 \mathrm{SiO}_{2}\right]$ with a molar ratio of 1:3.0 $(1.8 \mathrm{M})$, precursor, under microwave-assisted hydrothermal conditions at $150{ }^{\circ} \mathrm{C}$ for $1 \mathrm{~h}, \mathrm{pH}=10$.

FT-IR spectra of the HAp and Si-HAp powders revealed hydroxyl $\left(\mathrm{OH}^{-}\right)$groups stretching $\left(3571 \mathrm{~cm}^{-1}\right)$ and vibration $\left(631 \mathrm{~cm}^{-1}\right)$ bands (Figure 3). Furthermore, the strong bands at 1086, 1014, and $960 \mathrm{~cm}^{-1}$ wavenumbers are associated with the stretching vibration modes of $\mathrm{PO}_{4}{ }^{3-}$ tetrahedral group. The doublet band between 593 and $572 \mathrm{~cm}^{-1}$ corresponds to O-P-O bond bending mode and these results agree with the data reported elsewhere [14]. The shoulder peaked at $897 \mathrm{~cm}^{-1}$, and this band is assigned to the Si-O-Si vibration mode for tetrahedral $\mathrm{SiO}_{4}{ }^{4-}$ groups. A marked distortion of the shoulder peak together with the signals $v_{1}$ and $v_{3}$ of the P-O-P and $\mathrm{PO}_{4}{ }^{3-}$ major bands was found with progressive increases in the $\mathrm{SiO}_{4}{ }^{4-}$ molar content in the Si-HAp powders, as reported previously $[24,26]$. Furthermore, $v_{1}$ and $v_{3}$ bending modes of the P-O-P band gradually decreased in their absorbance by increasing the uptake of $\mathrm{Si}$ in the HAp structure, and a slight displacement to lower wavenumbers was revealed on the Si-HAp samples (Figure 3). In comparison with the FT-IR spectrum of pure HAP, the peak at $1086 \mathrm{~cm}^{-1}\left(\mathrm{PO}_{4}{ }^{3-}\right)$ in Si-HAp samples decreased as the silicon content uptake increased, due to the structural change in the HAp lattice [24-27]. Additionally, the intensity of the $\mathrm{OH}^{-}$group band on the 0.16 and $0.90 \mathrm{~mol} \% \mathrm{Si}$ samples was similar irrespective of the saturation contents of $\mathrm{Si}^{4+}$. On the contrary, the $\mathrm{OH}^{-}$stretching symmetrical band at $3571 \mathrm{~cm}^{-1}$ and bending $\mathrm{OH}^{-} 631 \mathrm{~cm}^{-1}$ markedly deceased in its absorbance in Si-HAp powders prepared with the highest concentration 1.8 M of TMAS (Figure 3c). XRD signals and FT-IT spectra confirm that the bulk Si should be incorporated in the apatite structure rather than partially existing at the particles' surface [26]. 


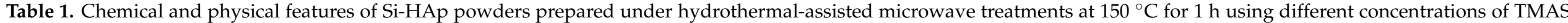
solutions and tripolyphosphate as a P precursor.

\begin{tabular}{|c|c|c|c|c|c|c|c|c|c|c|c|c|c|}
\hline \multirow[b]{2}{*}{$\begin{array}{l}\text { Sample* } \\
\text { Id Reference }\end{array}$} & \multirow{2}{*}{$\begin{array}{c}\text { Molar Con- } \\
\text { centration } \\
\mathbf{(} \pm \mathbf{0 . 0 0 1 )} \\
\text { of } \mathbf{S i}^{4+}\end{array}$} & \multicolumn{2}{|c|}{ Nominal Mol \% } & \multirow[b]{2}{*}{ Chemical Compositon $^{a}$} & \multirow[b]{2}{*}{$\begin{array}{l}\text { Molar } \\
\text { Ratio } \\
\mathrm{Ca} / \mathbf{P}\end{array}$} & \multirow[b]{2}{*}{ GOF $x^{2 b}$} & \multicolumn{3}{|c|}{ Lattice Parameter $^{b}$} & \multirow[b]{2}{*}{ Strain $^{b}$} & \multirow[b]{2}{*}{$\mathbf{R}_{\mathrm{wp}}$} & \multirow[b]{2}{*}{$\mathbf{R}_{\text {Bragg }}$} & \multirow[b]{2}{*}{$\begin{array}{l}\text { Crystallite } \\
\text { Size (nm) }\end{array}$} \\
\hline & & $\mathrm{PO}_{4}$ & $\mathrm{SiO}_{4}$ & & & & $a_{0}(\AA)$ & $c_{0}(\AA)$ & $\begin{array}{c}\text { Cell } \\
\text { Volume } \\
\left(\AA^{3}\right)\end{array}$ & & & & \\
\hline HAp & & 100 & 0 & $\mathrm{Ca}_{10}\left(\mathrm{PO}_{4}\right)_{6}(\mathrm{OH})_{2}$ & 1.667 & 1.36 & $9.4248(7)$ & $6.8764(5)$ & $528.97(0.09)$ & $0.5(0.02)$ & 9.43 & 1.44 & $51.69(2.3)$ \\
\hline MM62 & 0.3 & 94 & 6 & $\mathrm{Ca}_{10}\left(\mathrm{PO}_{4}\right)_{6}\left(\mathrm{SiO}_{4}\right)_{0.0}(\mathrm{OH})_{2}$ & 1.667 & 1.28 & $9.4433(10)$ & $6.8886(7)$ & $532.00(0.12)$ & $0.68(0.03)$ & 8.58 & 1.63 & $46.14(3.4)$ \\
\hline MM66 & 0.3 & 90 & 10 & $\mathrm{Ca}_{10}\left(\mathrm{PO}_{4}\right)_{5.99}\left(\mathrm{SiO}_{4}\right)_{0.01}(\mathrm{OH})_{1.99}$ & 1.667 & 1.66 & $9.4447(18)$ & $6.8869(8)$ & $532.10(0.22)$ & $0.53(0.08)$ & 10.89 & 3.08 & $46.64(4.9)$ \\
\hline MM63 & 0.3 & 80 & 20 & $\mathrm{Ca}_{10}\left(\mathrm{PO}_{4}\right)_{5.98}\left(\mathrm{SiO}_{4}\right)_{0.02}(\mathrm{OH})_{1.99}$ & 1.667 & 1.74 & $9.4439(16)$ & $6.8872(7)$ & $531.89(0.12)$ & $0.38(0.04)$ & 11.15 & 3.93 & $46.18(2.9)$ \\
\hline MM50 & 0.9 & 94 & 6 & $\mathrm{Ca}_{10}\left(\mathrm{PO}_{4}\right)_{5.975}\left(\mathrm{SiO}_{4}\right)_{0.025}(\mathrm{OH})_{1.975}$ & 1.674 & 1.64 & $9.4443(13)$ & $6.8866(11)$ & $531.97(0.19)$ & $0.56(0.07)$ & 10.86 & 3.18 & $45.03(3.7)$ \\
\hline MM51 & 0.9 & 90 & 10 & $\mathrm{Ca}_{10}\left(\mathrm{PO}_{4}\right)_{5.946}\left(\mathrm{SiO}_{4}\right)_{0.054}(\mathrm{OH})_{1.946}$ & 1.682 & 1.77 & 9.444413) & $6.8866(10)$ & $532.00(0.17)$ & $031(0.05)$ & 11.54 & 4.11 & $36.96(2.1)$ \\
\hline MM53 & 0.9 & 80 & 20 & $\mathrm{Ca}_{10}\left(\mathrm{PO}_{4}\right)_{5.699}\left(\mathrm{SiO}_{4}\right)_{0.301}(\mathrm{OH})_{1.699}$ & 1.755 & 1.27 & $9.4424(9)$ & $6.8863(6)$ & $531.73(0.11)$ & $0.30(0.03)$ & 8.24 & 1.71 & $35.94(1.2)$ \\
\hline MM64 & 1.8 & 94 & 6 & $\mathrm{Ca}_{10}\left(\mathrm{PO}_{4}\right)_{5.908}\left(\mathrm{SiO}_{4}\right)_{0.097}(\mathrm{OH})_{1.908}$ & 1.692 & 1.64 & $9.4475(16)$ & $6.8884(11)$ & $532.46(0.20)$ & $0.61(0.06)$ & 10.56 & 2.95 & $48.82(5.1)$ \\
\hline MM68 & 1.8 & 90 & 10 & $\mathrm{Ca}_{10}\left(\mathrm{PO}_{4}\right)_{5.633}\left(\mathrm{SiO}_{4}\right)_{0.367}(\mathrm{OH})_{1.633}$ & 1.775 & 1.30 & $9.4447(11)$ & $6.8872(8)$ & $532.09(0.14)$ & $0.68(0.04)$ & 8.44 & 1.81 & $48.64(3.4)$ \\
\hline MM65 & 1.8 & 80 & 20 & $\mathrm{Ca}_{10}\left(\mathrm{PO}_{4}\right)_{5.271}\left(\mathrm{SiO}_{4}\right)_{0.729}(\mathrm{OH})_{1.271}$ & 1.897 & 1.11 & $9.4365(9)$ & $6.8824(7)$ & $530.75(0.11)$ & $1.68(0.09)$ & 2.63 & 1.15 & $39.87(3.6)$ \\
\hline
\end{tabular}

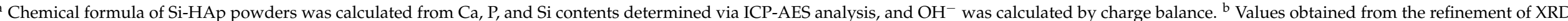

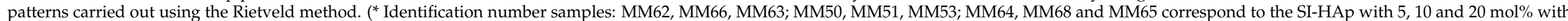
concentration $0.3,0.9$ and $1.8 \mathrm{M}$ respectively). 

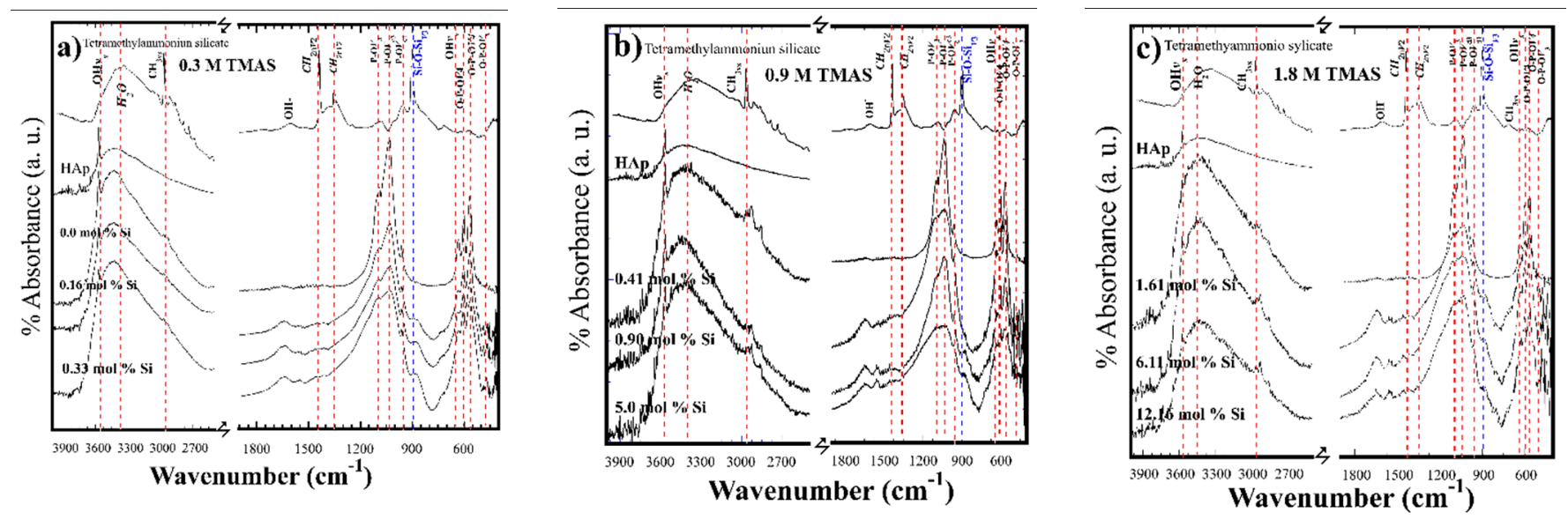

Figure 3. Fourier transform infrared (FT-IR) spectrum analysis of the Si-HAp powders obtained by microwave-assisted hydrothermal process at $150{ }^{\circ} \mathrm{C}$ for $1 \mathrm{~h}$ using different concentrations of $\left[\left(\mathrm{C}_{4} \mathrm{H}_{13} \mathrm{NO}_{5} \mathrm{Si}_{2}\right)\right.$ (TMAS)]: (a) $0.3 \mathrm{M}$; (b) $0.9 \mathrm{M}$, and (c) $1.8 \mathrm{M}$.

These structural results are consistent with the substitution mechanism proposed, where $\mathrm{PO}_{4}{ }^{3-}$ ions are replaced by $\mathrm{SiO}_{4}{ }^{4-}$ ions, causing a stoichiometric release of $\mathrm{OH}^{-}$ ions, which maintains the total charge balance in the HAp structure (Equation (1)). Under hydrothermal conditions, the saturation of $\mathrm{Si}^{4+}$ probably induced a reduction in the amount of hydroxyl groups to compensate for an extra negative electric charge produced by the incorporation of the silicate groups, and the formation of $\mathrm{OH}^{-}$vacancies $(V)$ might have taken place to maintain the charge balance neutrality, as is described by the following equation: $\mathrm{PO}_{4}{ }^{3-}+\mathrm{OH}^{-} \rightarrow \mathrm{SiO}_{4}{ }^{4-}+V_{(\mathrm{OH})-}$. Indeed, this behavior is consistent with previous research work [13].

Raman analyses were carried out to determine detailed crystalline differences in the bonds. Raman spectra of the SiHAp constituents in Figure 4a show that the $v_{1}$ symmetric stretching $\mathrm{PO}_{4}$ mode at around $996 \mathrm{~cm}^{-1}$ corresponds to the HAp structure of the prepared Si-HAp powders samples with both concentrations $(0.9$ and $1.8 \mathrm{M})$. Other typical $\mathrm{PO}_{4}$ peak modes of the bending $v_{2}$, asymmetric stretching $v_{3}$, and bending $v_{4}\left(\mathrm{PO}_{4}\right)$ were also observed at around 400,1100, and $600 \mathrm{~cm}^{-1}$, respectively. The progressive decrease in the peak intensity and their broadening for all $\mathrm{PO}_{4} v_{2}-v_{4}$ bands confirmed the $\mathrm{SiO}_{4}{ }^{4-}$ substitution by $\mathrm{PO}_{4}{ }^{3-}$ group. The $\mathrm{OH}^{-}$peak intensity decreased with broadening of the band [20]; these results are in line with those of FT-IR and XRD. Under hydrothermal conditions assisted by microwave heating, the molar percentage of $\mathrm{Si}^{4+}$ substitution was larger than $10 \mathrm{~mol} \%$ by providing a 9 -fold saturated $\mathrm{Si}^{4+}$ precursor in comparison with the stoichiometric limit of acceptance to keep the stability of the HAp structure. This explains the low variation of the lattice parameter and very small variation in the crystallite size, because only $0.33 \mathrm{~mol} \%$ of $\mathrm{Si}^{4+}$ was incorporated in the HAp structure for samples prepared with a low concentration of TMAS $(0.3 \mathrm{M})$. However, Si-HAp samples synthesized with a greater content of $\mathrm{Si}^{4+}(12.16 \mathrm{~mol} \%)$ did not show the presence of the characteristic $\mathrm{Si}$ signal, and only small changes were detected in the vibration $\mathrm{OH}^{-}$signal at $3570 \mathrm{~cm}^{-1}$, which were slightly decreased and broadened under the high $\mathrm{Si}^{4+}$ saturation of TMAS $(1.8 \mathrm{M})$ during the hydrothermal reaction. 

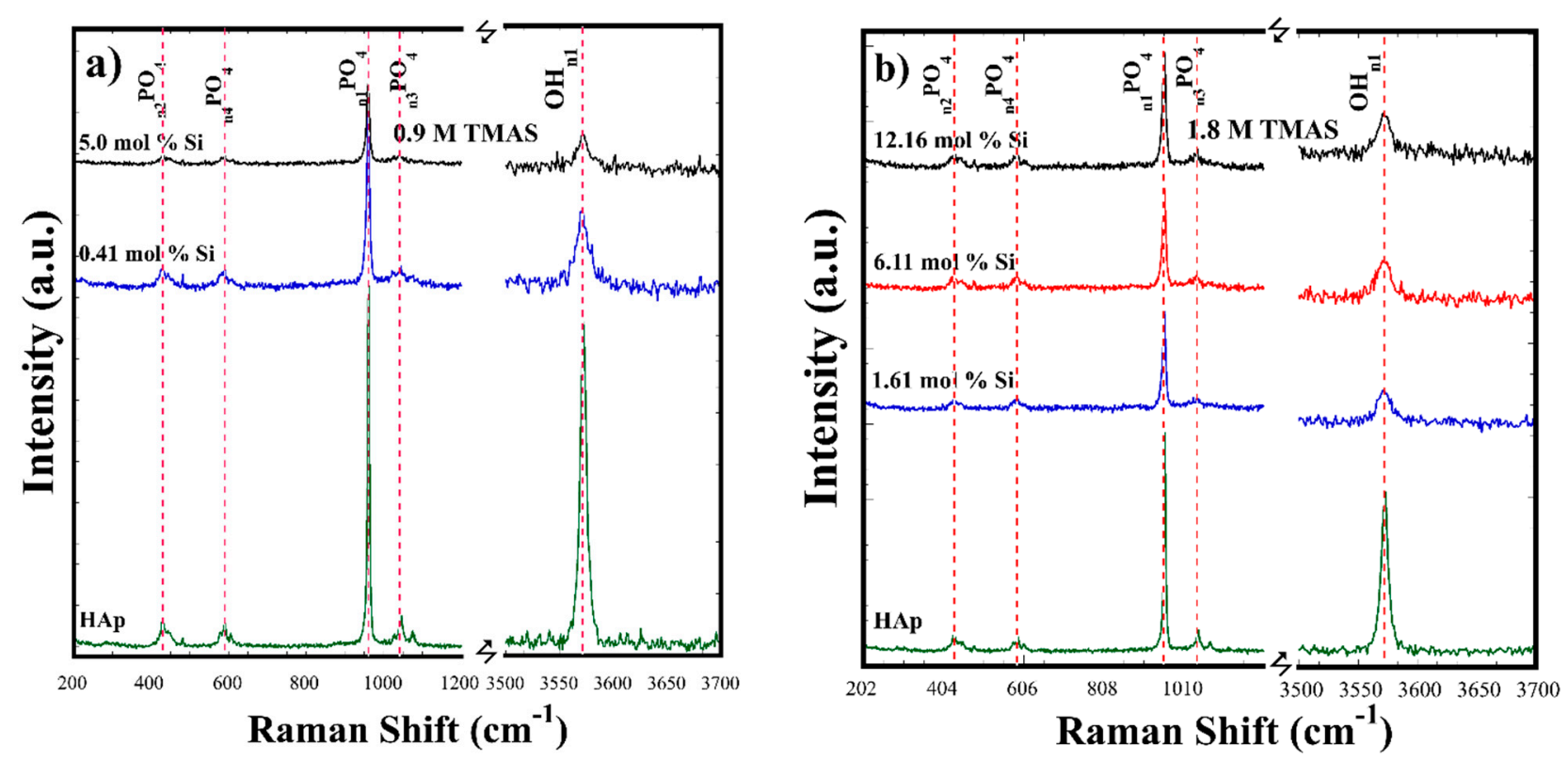

Figure 4. Raman spectra of the Si-HAp powders obtained by microwave assisted hydrothermal process at $150{ }^{\circ} \mathrm{C}$ for $1 \mathrm{~h}$ using different molar concentrations of the TMAS solutions: (a) 0.9 and (b) $1.8 \mathrm{M}$.

Figure 5a-d shows the XPS spectra for HAp and Si-HAp powders prepared with a $0.9 \mathrm{M}$ solution for samples with ultimate contents of 5 and $12.16 \mathrm{~mol} \% \mathrm{Si}$. The XPS spectra corresponding to the photoelectron core levels of Ca 2p, P 2p, Si $2 p$, and O 1s without any additional core level of other elements were detected by the XPS analyses in the survey spectrum. Generally, the Ca $2 p$ spectrum recorded in the binding energy (BE) range of 344.0-355.0 eV revealed the doublet associated with Ca-O bonds in the HAp and Si-HAp samples, which are constituted by the core level $\mathrm{Ca} 2 \mathrm{p}_{3 / 2}$ at $347.21 \mathrm{eV}$ and $\mathrm{Ca}$ $2 p_{1 / 3}$ at $350.55 \mathrm{eV}$ BE. Furthermore, the $\mathrm{P} 2 \mathrm{p}$ peak is symmetric and its average $\mathrm{BE}$ is at $132.9 \mathrm{eV}$ both for HAp and Si-HAp (Figure 5b). Moreover, the O 1s core level peak was deconvoluted into two peaks, and a small peak, which fits the shoulder between 532 and $534 \mathrm{eV}$, was detected. The deconvolution indicates that the peak average BE energy was of $532.45 \mathrm{eV}$, and this peak is associated with the $\mathrm{SiO}_{4}$ units in the prepared powder samples, where the gradual increase in peak intensity in the samples synthesized with different $\mathrm{Si}^{4+}$ contents supports our inference (Figure 5c). The second large peak, deconvoluted at an average $\mathrm{BE}$ of $530.8 \mathrm{eV}$, corresponded to the $\mathrm{O} 1 \mathrm{~s}$ core level of $\mathrm{PO}_{4}{ }^{3-}$ tetrahedral units. However, the presence of silicon was very clear in powders prepared with $0.41 \mathrm{~mol} \% \mathrm{Si}$, as shown in Figure 5d. In contrast, a symmetric peak corresponding to the core level $\mathrm{Si}$ $2 p$ at $\mathrm{BE}$ of $103.3 \mathrm{eV}$ was revealed in the Si-HAp samples obtained with the molar volume corresponding to $5.0 \mathrm{~mol} \% \mathrm{Si}$ using the TMAS solution of $0.9 \mathrm{M}$. 

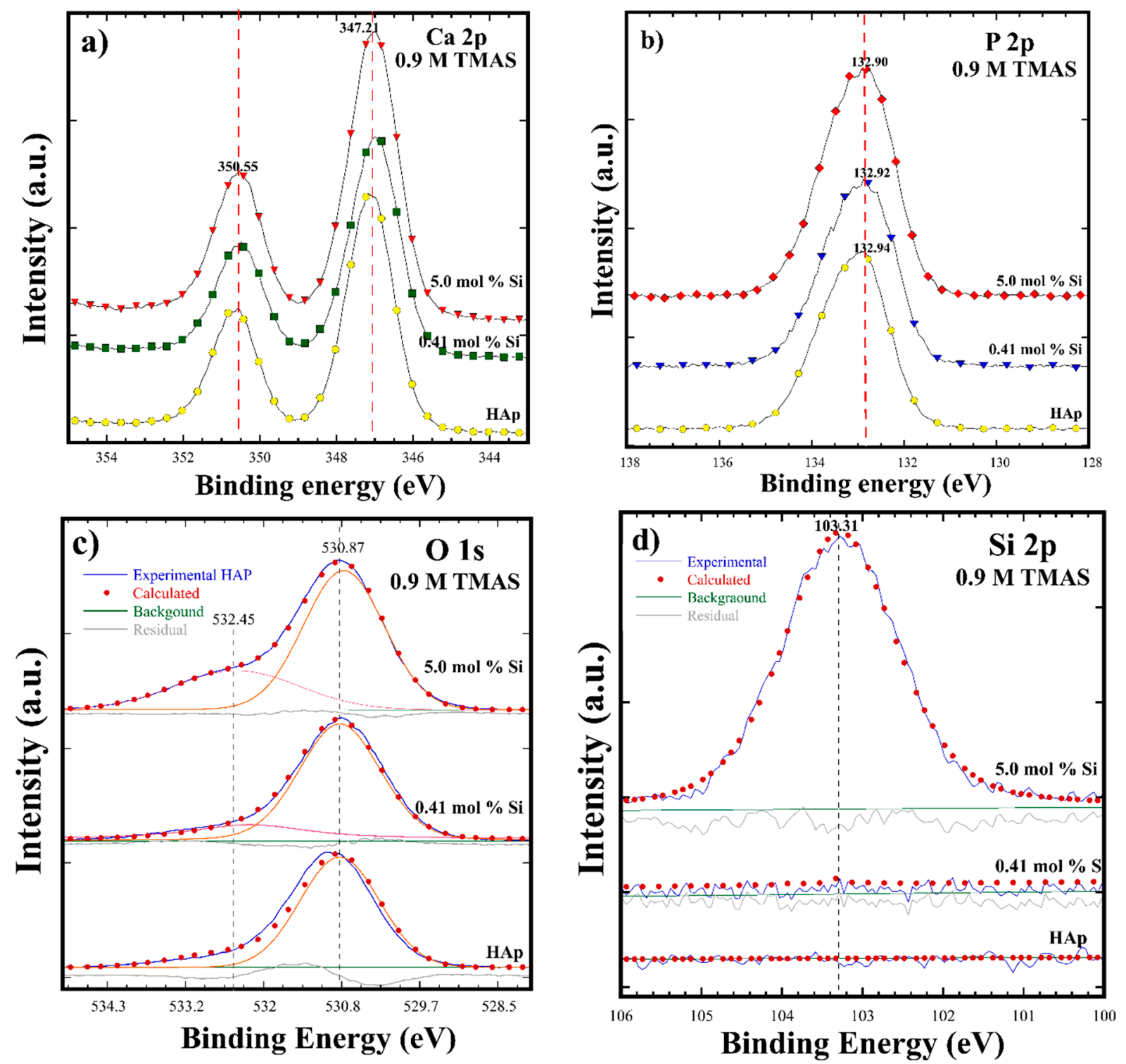

Figure 5. The XPS analysis for HAp and Si-HAp powders obtained by microwave assisted hydrothermal process at $150{ }^{\circ} \mathrm{C}$ for $1 \mathrm{~h}$ using $0.9 \mathrm{M}$ of TMAS and different mol\% of Si: (a) Ca 2p; (b) P 2p; (c) O 1s; (d) Si 2p.

The XPS spectra in Figure 6 indicated that HAp and Si-HAp powders prepared in the presence of the highest $\mathrm{Si}^{4+}$ saturated TMAS solution $(1.8 \mathrm{M})$ exhibited a gradual uptake of $\mathrm{Si}$. All the samples are constituted by the chemical elements that form the HAp structure. Figure 6a shows the typical doublet peak associated with the core level Ca 2 $\mathrm{p}_{3 / 2}$ XPS BE at $347.1 \mathrm{eV}$ and $\mathrm{Ca} 2 \mathrm{p}_{1 / 3}$ at $350.07 \mathrm{eV}$. The doublet peaks increased slightly as the silicon incorporation content increased in the synthesized samples obtained with $1.61 \mathrm{~mol} \%$ of $\mathrm{Si}$ in the Si-HAp powders. Likewise, the symmetric signals of $\mathrm{P} 2 \mathrm{p}$ increased slightly with the increase of $\mathrm{Si}^{4+}$ content, achieving a binding energy of $132.92 \mathrm{eV}$. Furthermore, the binding energy signals for $\mathrm{O} 2 \mathrm{p}$ peaks were nearly symmetric (Figure $6 \mathrm{c}$ ). The main component at $530.9 \mathrm{eV}$ corresponding to the $\mathrm{O}^{2-}$ is linked only to a phosphorus atom as in $\mathrm{PO}_{4}{ }^{3-}$ ions of the HAp structure. With the increase of the $\mathrm{mol}^{\circ}$ of $\mathrm{SiO}_{4}{ }^{4-}$ in the prepared powders, the $\mathrm{BE}$ signal shifted slightly into $530.79 \mathrm{eV}$ and a shoulder peak at an average BE of $532.53 \mathrm{eV}$ increased [11]. Therefore, this shoulder peak is attributed to the $\mathrm{O}^{2-}$ ions associated with the $\mathrm{SiO}_{4}{ }^{4-}$ tetrahedral units. 

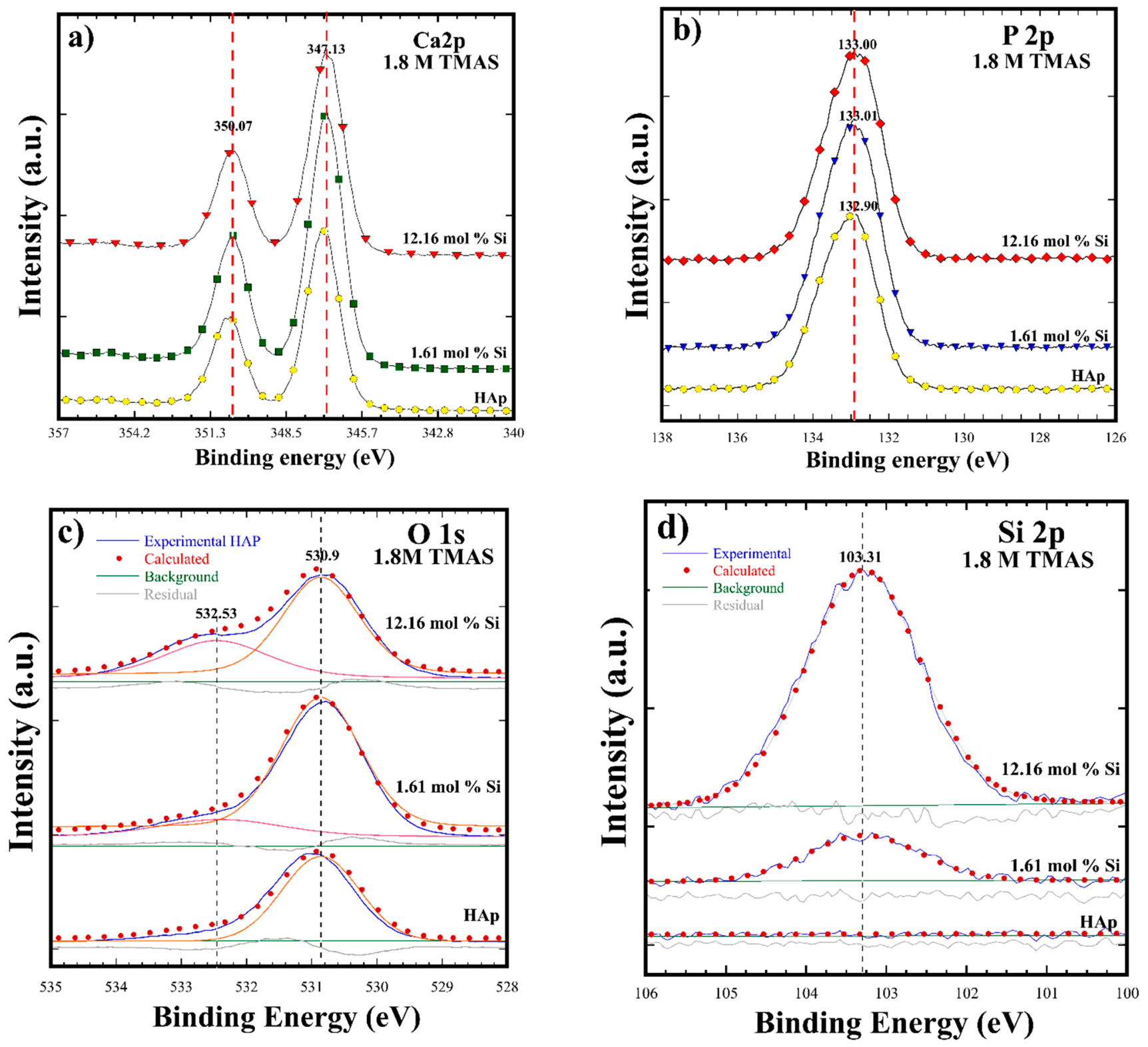

Figure 6. The XPS analysis for HAp and Si-HAp powders obtained by microwave assisted hydrothermal process at $150{ }^{\circ} \mathrm{C}$ for $1 \mathrm{~h}$ using 1.8 M of the TMAS solutions with different mol\% Si: (a) Ca 2p; (b) P 2p; (c) O 1s; (d) Si 2p.

In addition, the presence of $\mathrm{Si}$ was confirmed in the HAp structure of the powders prepared using the highest saturation of Si (9-fold, Figure 6d). The XPS core level Si $2 \mathrm{p}$ corresponded to the symmetric peak at $\mathrm{BE}$ of $103.18 \mathrm{eV}$ for the $1.61 \mathrm{~mol} \% \mathrm{Si}$. The Si $2 p$ peak intensity increased as a result of the improved $\mathrm{SiO}_{4}{ }^{4-}$ incorporation in the HAp structure. The largest peak at a $\mathrm{BE}$ of $103.31 \mathrm{eV}$ occurred in the sample containing $12.16 \mathrm{~mol} \% \mathrm{Si}$, and this SiHAp powder exhibited similar BE behavior as was reported elsewhere $[20,21]$. The lack of Si uptake in the HAp structure would be caused by the highly soluble species produced by the TMAS precursor, such as $(\mathrm{Si}-\mathrm{O}-\mathrm{Si})_{3} \mathrm{O}^{-}$. This anionic specie is preferentially formed in methanolic solutions due to the high solubility property of TMAS [22-27]. Therefore, these species should reduce the solute concentration of $\mathrm{SiO}_{4}{ }^{4-}$ ions at the supersaturation stage reached under microwave-assisted hydrothermal conditions. This behavior is attributed to the fact that the TMAS might dissolve in 2propanol under the hydrothermal fluid forming silicate ions in the medium. The highly soluble silicate ions themselves promote polymerization of silicate ions, limiting the amount of $\mathrm{OH}^{-}$ions in the SiHAp powders, because the related vibration $\mathrm{OH}^{-}$signal in FT-IR 
spectra decreased slightly under the high $\mathrm{Si}^{4+}$ saturation of TMAS $(1.8 \mathrm{M})$ during the hydrothermal reaction.

\subsection{Morphological Aspects of the Partially Substituted Si-HAp Particles Prepared Hydrothermally}

The morphology of HAp and Si-HAp powders was analyzed by FE-SEM micrographs (Figure 7). Pure HAp was determined to be monodispersed particles with a regular rod-like morphology with an average size of $62 \mathrm{~nm}$. In contrast, the Si-HAP powders were mostly monodispersed Si-HAp agglomerates with a quasi-oval shape. The agglomerates average size of the Si-HAp samples incorporating $0.9 \mathrm{~mol} \%$ of $5.0 \mathrm{~mol} \% \mathrm{Si}$ contents was between $235.5 \pm 29.7$ and $297.4 \pm 19.4 \mathrm{~nm}$. Whilst, when the 9-fold $\mathrm{Si}^{4+}$ sutured TMAS solution $(1.8 \mathrm{M})$ was used, the agglomerated average size of the samples with $6.11 \mathrm{~mol} \%$ and $12.16 \mathrm{~mol} \% \mathrm{Si}$ contents was between $243.9 \pm 22.2$ and $315.1 \pm 22.5 \mathrm{~nm}$. The excess of $\mathrm{Si}$ in the hydrothermal medium should trigger the formation of Si-HAp agglomerates prepared under fast kinetic reaction conditions assisted by the microwave heating. These results are supported by variation in the crystallite size, as calculated in the Rietveld refinement results (Table 1 ).
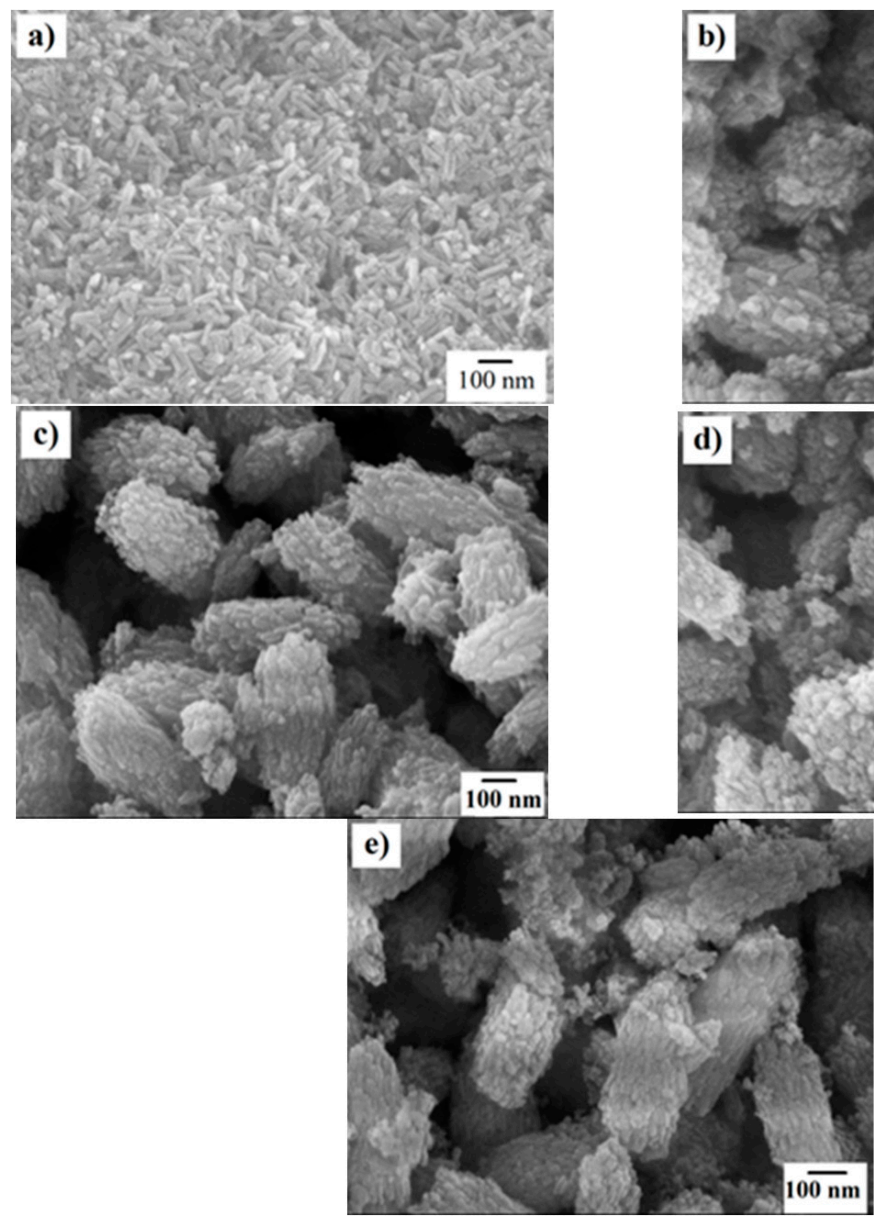
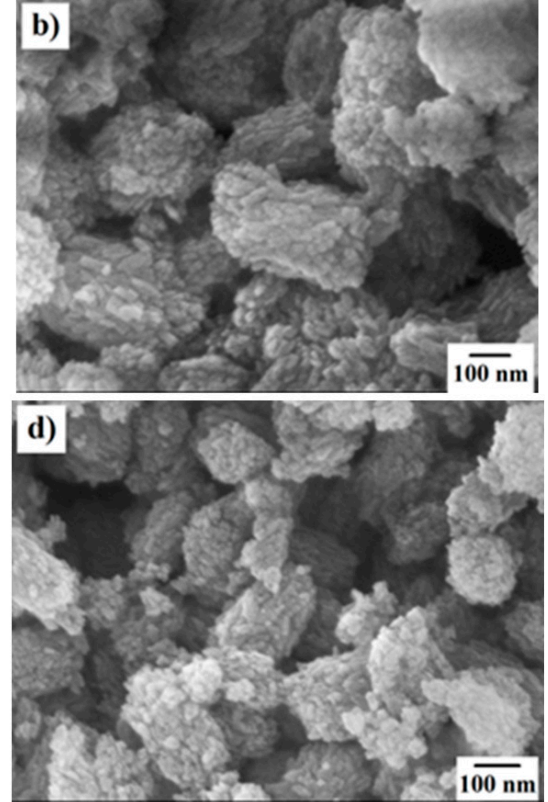
$\overline{100 \mathrm{~nm}}$

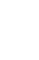


irrespective of the $\mathrm{Si}^{4+}$ saturation in the reaction fluid medium. Generally, the agglomerates are formed by nanosized euhedral rod-shaped crystals with varied sizes. The rod-shaped crystals containing $1.62 \mathrm{~mol} \% \mathrm{Si}$ exhibited a broad monomodal length distribution, and the average length was $32 \pm 8.0 \mathrm{~nm}$ (Figure $8 \mathrm{a}, \mathrm{b}$ ). On the contrary, a slight reduction in the crystal length occurred in the Si-HAp sample incorporating $12.15 \mathrm{~mol} \% \mathrm{Si}$, which was shorter than in the sample incorporating $1.62 \mathrm{~mol} \mathrm{Si}$, and the length size distribution curve revealed it to be in a vast proportion $(27.0 \pm 8.0 \mathrm{~nm}$ ) (Figure $8 \mathrm{~d}$,e). The Si- HAp particle size gradually decreased with the increase of $\mathrm{Si}$ content. In addition, HR-TEM and SAED provide a high crystallinity of the euhedral rod-shaped SiHAp particles incorporating both $1.62 \mathrm{~mol} \%$ and $12.15 \mathrm{~mol} \% \mathrm{Si}$ (Figure $8 \mathrm{c}, \mathrm{f})$. The SAED pattern (inset) of the squared area in Figure $8 \mathrm{c}$ indicates that the preferential stacking of the $1.62 \mathrm{~mol} \% \mathrm{Si}-\mathrm{HAp}$ crystals proceeds along the hexagonal structure basal plane with a Miller index of (300), although an irregular atomic stacking occurred in some areas of the agglomerate $12.15 \mathrm{~mol} \% \mathrm{Si}$. Meanwhile, the SAED pattern of the crystals indicated that the agglomerates containing less silicon were associated with the family plane $<112>$ Miller index. The interplanar spacing calculated for the (112) and (211) planes was $0.32 \mathrm{~nm}$ and $0.27 \mathrm{~nm}$, respectively. These values are very close to the interplanar spacing positions in the single-phase hydroxyapatite structure. The SAED patterns confirmed that the fine, rod-like Si-HAp crystals are single crystals.
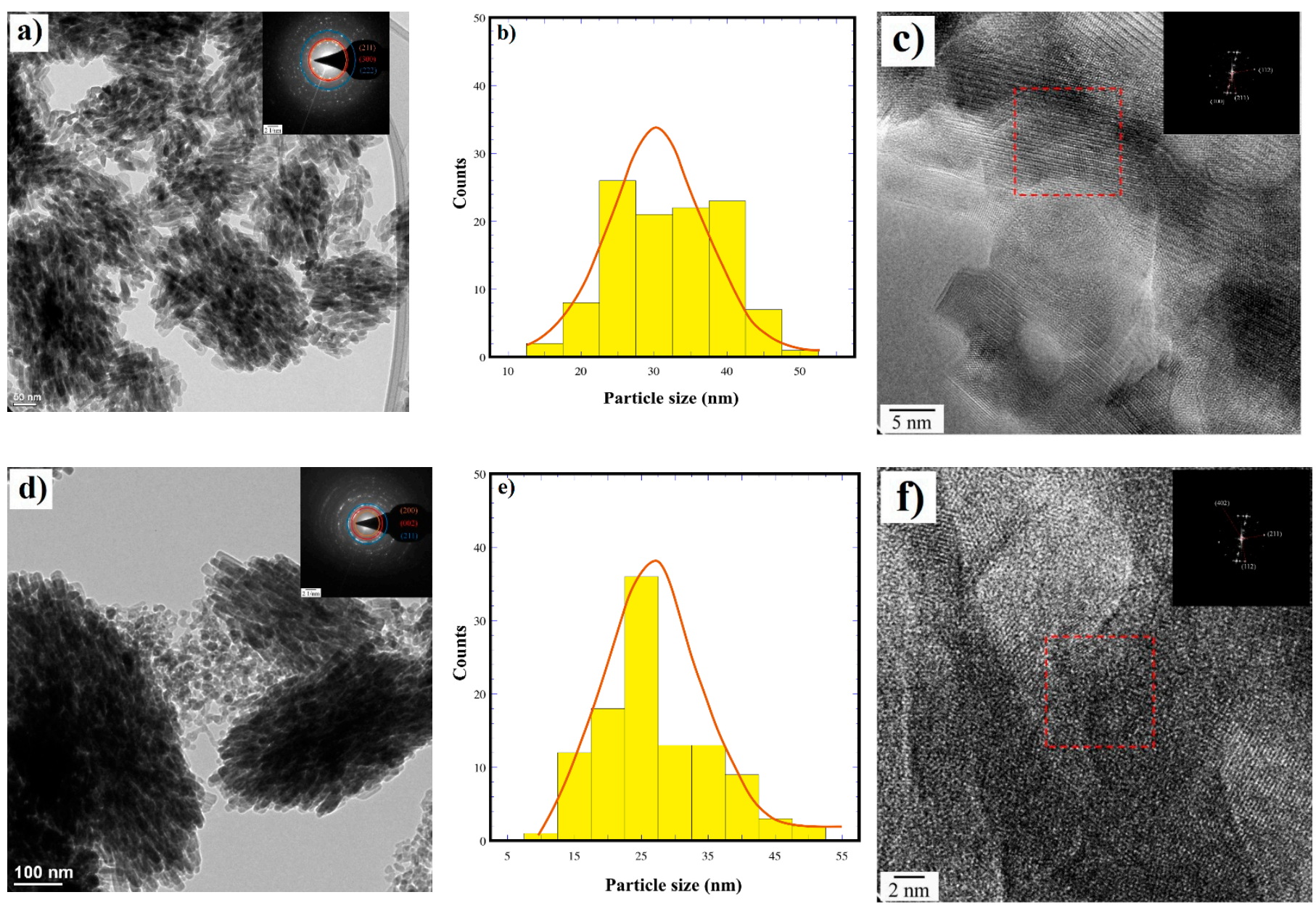

Figure 8. HRTEM micrographs of the Si-HAp powders prepared under an assisted hydrothermal process at $150{ }^{\circ} \mathrm{C}$ for $1 \mathrm{~h}$ using [( $\left.\mathrm{C}_{4} \mathrm{H}_{13} \mathrm{NO}_{5} \mathrm{Si}_{2}\right)$ (TMAS)] $1.8 \mathrm{M}$ : (a-c) $1.62 \mathrm{~mol} \%$ of $\mathrm{Si}$ and $(\mathbf{d}-\mathbf{f}) 12.15 \mathrm{~mol} \%$ of $\mathrm{Si}$.

SEM and HR-TEM observations indicated that the $\mathrm{Si}^{4+}$ excess in the hydrothermal medium led to a marked variation in the growth and the spontaneous assembly process of the euhedral rod-like particles. These differences should be generated from a differ- 
ent dissolution-crystallization mechanism, which achieved rapid reaction kinetics by the microwave heating of the hydrothermal medium at $150{ }^{\circ} \mathrm{C}$. However, the formation of highly soluble anionic silicate tri-branching units $(\mathrm{Si}-\mathrm{O}-\mathrm{Si})_{3} \mathrm{O}^{-}\left(\mathrm{Q}^{3}\right)$ could form to become dominant under the current hydrothermal conditions due to the addition of 2-propanol [28]. The $\mathrm{Q}^{3}$ units, which can act as fine micelles that trap the Si-HAp nutrients, led to a certain supersaturation state in the hydrothermal reaction conditions, which should be essential for the crystallization of the irregular oval-shaped Si-HAp agglomerates. When a further excess of $\mathrm{Si}^{4+}$ was supplied, the molar volume of the $\mathrm{Q}^{3}$ units increased, leading to an increase in the agglomerate size. The above inference, associated with the reaction pathway, is supported by the fact that no crystalline $\mathrm{SiO}_{2}$ species were formed as a secondary phase as a result of the crystallization of the $Q^{3}$ units. Hence, we surmise that the hydrothermal microwave-assisted method is efficient to produce Si-HAp powders with larger contents of silicon rather than those techniques reported recently [12] including the conventional hydrothermal process [22]. This method coupled with the use of TMAS has the potential for processing Si-HAp to prepare biomaterials with implant applications in medicine.

\section{Conclusions}

Si-HAp powders were successfully crystallized under fast microwave-assisted hydrothermal synthesis conditions at a low temperature $\left(150{ }^{\circ} \mathrm{C}\right)$ for $1 \mathrm{~h}$ using saturated $\mathrm{Si}^{4+}$ precursor TMAS solutions.

The maximum amount of $\mathrm{Si}^{4+}$ incorporated in the HAp structure was $12.16 \mathrm{~mol} \%$, using an excess of $1.8 \mathrm{M}$ of TMAS. The addition of highly concentrated $\mathrm{Si}^{4+}$ solutions $(0.3-1.8 \mathrm{M})$ caused differences on the crystalline unit cell of the apatite and produced agglomerates constituted by fine euhedral rod-like crystal with an average length of $27.0 \pm 8.0 \mathrm{~nm}$ and a single crystal habit. The $\mathrm{Si}^{4+}$ excess in the reaction media led to the rod-like crystal self-assembly to produce irregular oval-shaped Si-HAp agglomerates, which were prepared under fast kinetic reaction conditions assisted by the microwave heating and exhibit sizes between 233.5 and $315.1 \mathrm{~nm}$. These agglomerates exhibited a marked size coarsening, which was triggered by the $\mathrm{Si}^{4+}$ saturation level supplied in the hydrothermal media. Despite the $\mathrm{Si}^{4+}$ ion high level of saturation used in the hydrothermal reaction medium, the lack of $\mathrm{Si}$ incorporation in the HAp structure is promoted by the $\mathrm{Q}_{3}$ species, namely $(\mathrm{Si}-\mathrm{O}-\mathrm{Si})_{3} \mathrm{O}^{-}$, which are likely formed in hydrothermal media containing 2-propanol. These highly soluble ions reduced the supersaturation $\mathrm{SiO}_{4}{ }^{4-}$ molar volume in the medium, almost 50\% below the ultimate stoichiometric content selected. Furthermore, a remarkable decrease in the $\mathrm{O}$ - ions content was confirmed by FTIR and XPS analyses, and the gradual $\mathrm{OH}^{-}$lost was caused to compensate for the partial incorporation of $\mathrm{SiO}_{4}{ }^{4-}$ at tetrahedral $\mathrm{PO}_{4}{ }^{3-}$ sites in the HAp structure. The present hydrothermal microwaveassisted method has delivered high processing efficiency to crystallize Si-HAp particles with a control on the $\mathrm{Si}^{4+}$ content. This method has potential for processing Si-HAp bioceramic implants in medicine.

Author Contributions: Z.M.-V. conceptualized, designed, and organized the research work; J.C.R.A. provided the infrastructure and microwave autoclaves; B.M.-P. conducted the hydrothermal experiments; J.C.R.-A. and Z.M.-V. conducted the chemical and crystalline structural characterization and data analysis; K.Z. contributed to the XPS and Raman characterization; K.Y. and T.U. provided the infrastructure to conduct the characterization; Z.M.-V. wrote the manuscript. All authors have read and agreed to the published version of the manuscript.

Funding: This research was financially supported by "Research Projects grants TecNM: 6273.17-P" and partially supported by project grant TecNM 5931.19-P, to support PNPC, SNI-CONACYT of the "Instituto Tecnológico de Saltillo", Mexico. B.M.-P. is indebted to CONACYT, Mexico for financial support in a PhD Scholarship to conduct a part of this research.

Institutional Review Board Statement: Not applicable.

Informed Consent Statement: Not applicable. 
Data Availability Statement: The data presented in this study are available in the Hydrothermal Synthesis of Nanoparticles knowledgebase https:/ / www.mdpi.com/journal/nanomaterials/special_ issues/hydrotherm_nano, accessed on 10 May 2021.

Acknowledgments: Z.M.-V. and J.C.R.-A. are indebted to the CONACYT-SNI. This study was kindly supported by Center for Advanced Marine Core Research, Kochi University for the use of the FE-SEM and XRD equipment.

Conflicts of Interest: The authors declare no conflict of interest. The funders had no role in the study, or analysis and interpretation of data; in writing the manuscript; or the decision to publish the results.

\section{References}

1. Kongjun, Z.; Yanagisawa, K.; Shimanouchi, R.; Onda, A.; Kajiyoshi, K.; Qiu, J. Synthesis and crystallographic study of Pb-Sr hydroxyapatite solid solutions by high temperature mixing method under hydrothermal conditions. J. Ceram. Soc. Jpn. 2007, 115, 873-876. [CrossRef]

2. Carlisle, E.M. Silicon: A possible factor in bone calcification. Science 1970, 167, 279-280. [CrossRef] [PubMed]

3. Lee, J.H.; Lee, K.S.; Chang, J.S.; Cho, W.S.; Kim, Y.; Kim, S.R.; Kim, Y.T. Biocompatibility of Si-substituted hydroxyapatite. J. Key Eng. Mater. 2004, 254-256, 135-138. [CrossRef]

4. Gibson, I.R.; Huang, J.; Best, S.M.; Bonfield, W. Enhanced in vitro cell activity and surface apatite layer formation on novel silicon-substituted hydroxyapatites. World Sci. 2009, 12, 191-194. [CrossRef]

5. Jamil, M.; Elouatli, B.; Khallok, H.; Jamil, M.; Elouahli, A.; Gourri, E.; Ezzahmouly, M.; Abida, F.; Hatim, Z. Silicon substituted hydroxyapatite: Preparation with solid-state reaction, characterization and dissolution properties. J. Mater. Environ. Sci. 2018, 9, 2322-2327.

6. Harden, F.J.; Gibson, I.R.; Skakle, J.M.S. Simplification of the synthesis method for silicon-substituted hydroxyapatite: A Raman spectroscopy study. Key Eng. Mater. 2012, 529, 94-99. [CrossRef]

7. Marchat, D.; Zymelka, M.; Coelho, C.; Gremillard, L.; Jolypottuz, L.; Babonneau, F.; Esnouf, C.; Chevalier, J.; Nernacheasollant, D. Accurate characterization of pure silicon-substituted hydroxyapatite powders synthesized by a new precipitation route. Acta Biomater. 2013, 9, 6992-7004. [CrossRef]

8. Zou, S.; Huang, J.; Best, S.; Bonfield, W. Rietveld studies on silicon substituted hydroxyapatite. Key Eng. Mater. 2006, 309, 113-116. [CrossRef]

9. Nakahira, A.; Nakata, K.; Numako, C.; Murata, H.; Matsunaga, K. Synthesis and evaluation of calcium-deficient hydroxyapatite with $\mathrm{SiO}_{2}$. Mater. Sci. Appl. 2011, 2, 1194-1198. [CrossRef]

10. Outali, B.E.; Jamil, M.; Elouahli, A.; Ezzahmouly, M.; Abida, F.; Ilou, M.; Hatim, Z. Silicon substitution in biphasic calcium phosphate bioceramics: Crystal structure study. Int. J. Sci. Eng. Res. 2016, 7, 829-833.

11. Yacoubi, A.E.; Massit, A.; Fathi, M.; Chafik, B.; Idrissi, E.; Yammi, K. Characterization of silicon-substituted hydroxyapatite powders synthesized by a wet precipitation method. IOSR J. Appl. Chem. 2014, 7, 24-29. [CrossRef]

12. Aminian, A.; Solati, M.; Bakhshi, F.; Fazardi, A. Silicon substitution hydroxyapatite by hydrothermal method. Adv. Bioceram. Biotechnol. 2010, 11, 59-65.

13. Gibson, I.R.; Best, S.M.; Bonfield, W. Chemical characterization of silicon-substituted hydroxyapatite. J. Biomed. Mater. Res. 1999, 44, 422-428. [CrossRef]

14. Aminian, A.; Salti-Hashjin, M.; Samadikuchaksaraei, A.; Bakhshi, F.; Gorjipour, F.; Farzadi, A.; Motztarzadath, F.; Schmucker, M. Synthesis of silicon-substitute hydroxyapatite by a hydrothermal method with two different phosphorous sources. Ceram. Int. 2011, 37, 1219-1229. [CrossRef]

15. Bulina, N.; Chaikina, M.V.; Ishchenko, A.V.; Prosanov, I.Y. Mechanochemical synthesis of $\mathrm{SiO}_{4}{ }^{4-}$-substituted hydroxyapatite, part II-Reaction mechanism, structure, and substitution limit. Eur. J. Inorg. Chem. 2014, 28, 4803-4809. [CrossRef]

16. Neira, I.S.; Kolen'ko, V.Y.; Lebedev, O.I.; Tendeloo, G.V.; Gupta, H.S.; Guitian, F.; Yoshimura, M. An effective morphology control of hydroxyapatite crystals via hydrothermal synthesis. Cryst. Growth Des. 2009, 9, 466-467. [CrossRef]

17. Byrappa, K.; Yoshimura, M. Handbook of Hydrothermal Technology a Technology for Crystal Growth and Materials Processing; William Andrew Publishing, LLC: Norwich, NY, USA, 2010; pp. 755-780. ISBN 9781437778366.

18. Yanagisawa, K.; Toya, H.; Feng, Q.; Yamasaki, N. In situ formation of hydroxyapatite crystals under hydrothermal conditions. Phosphorus Res. Bull. 1995, 5, 43. [CrossRef]

19. Padmanabhan, S.K.; Haq, U.E.; Licciulli, A. Rapid synthesis and characterization of silicon substituted nano hydroxyapatite using microwave irradiation. Curr. Appl. Phys. 2014, 14, 87-92. [CrossRef]

20. Montoya, K.L.; Rendón-Ángeles, J.C.; Matamoros-Veloza, Z.; Yanagisawa, K. Rapid synthesis and characterization of Zn substituted hydroxyapatite nanoparticles via a microwave-assisted hydrothermal method. Mater. Lett. 2017, 195, 5-9. [CrossRef]

21. Lamkhao, S.; Phaya, M.; Jansakun, C.; Chandet, N.; Thongkorn, K.; Rujijanagul, G.; Bangrak, P.; Randorn, C. Synthesis of hydroxyapatite with antibacterial properties using a microwave-assisted combustion method. Sci. Rep. Springer Nat. $2019,9,4015$. [CrossRef] 
22. Moreno Perez, B.; Matamoros Veloza, Z.; Rendon-Angeles, J.C.; Yanagisawa, K.; Onda, A.; Perez Terrazas, J.E.; Mejia Martinez, E.E.; Burciaga Diaz, O.; Rodriguez Reyes, M. Synthesis of silicon-substituted hydroxyapatite using hydrothermal process. Bol. De La Soc. Española De Cerámica Y Vidr. 2020, 59, 50-64. [CrossRef]

23. Hasegawa, I.; Sakka, S.; Sugahara, Y.; Kuroda, K.; Kato, C. Silicate anions formed in tetramethylammonium silicate methanolic solution as studied by 29 Si nuclear magnetic resonance. J. Chem. Soc. Chem. Commun. 1989, 4, 208-210. [CrossRef]

24. Yoichiro, M.; Masateru, H.; Masahiko, O.; Toshihiro, K.; Masayuki, N. Large-sized hydroxyapatite whiskers derived from calcium tripolyphosphate gel. J. Euro. Ceram. Soc. 2005, 25, 3181-3185. [CrossRef]

25. Shing, H.Y.; Jung, J.Y.; Kim, S.W.; Lee, W.K. XPS analysis on chemical properties of calcium phosphate thin films and osteoblastic HOS cell responses. J. Ind. Eng. Chem. 2006, 12, 476-483.

26. Bianco, A.; Cacciotti, I.; Lombardi, M.; Montanaro, L. Si-substituted hydroxyapatite nanopowders: Synthesis, thermal stability and sinterability. Mater. Res. Bull. 2009, 44, 345-354. [CrossRef]

27. Younes, B.; Meriame, B.; Ferreira, J.; El Mabrouk, K. Hydrothermal synthesis of Si-doped hydroxyapatite nanopowders: Mechanical and bioactivity evaluation. Int. J. Appl. Ceram. Technol. 2015, 12, 329-340. [CrossRef]

28. Botelho, C.M.; Lopes, M.A.; Gibson, I.R.; Best, S.M.; Santos, J.D. Structural analysis of Si-substituted hydroxyapatite: Zeta potential and X-ray photoelectron spectroscopy. J. Mater. Sci. Mater. Med. 2002, 13, 1123-1127. [CrossRef] 